\title{
Perception and Interpretation Problems of Contemporary Approaches of the Concept of Jihad*
}

\author{
Abdulhakim Allahdad ${ }^{1}$
}

\begin{abstract}
In recent decades, the concept of jihad, an essential concept in Islamic disciplines, in particular in Islamic jurisprudence, has turned into one of the most discussed and debated terms across the globe. The concept of jihad, though, has always maintained its vitality in the religious, scholarship, military and political spheres throughout Islamic history; however, after the September 11 incident, enormous and remarkable studies have been carried out on the concept of jihad by many thinktanks, universities, academic institutions, political and military organizations across the globe. In these studies, the concept of jihad has been understood, analyzed, defined and interpreted differently, and used, represented and interpreted beyond its context. This study, thus, has attempted to explore these contemporary interpretations and approaches to the concept of jihad. Considering the recent decades' interpretations, one can observe that four types of approach have been prevalent: reductionist, radical, defensive, and Islamophobic approach. In this context, this study consisted of five main sections: the first section dealt with the use of the concept of jihad in the primary sources of Islam (Qur'an and Sunnah), and Islamic disciplines. In the remained four sections; the main arguments, discourses, and shreds of evidence of the reductionist, radical, defensive and Islamophobic approaches have been touched respectively and thoroughly.
\end{abstract}

\section{Keywords}

Jihad • Islamic Jurisprudence • Warfare • Reductionist Approach • Radical Approach • Defensive Approach • Islamophobic Approach.

* This paper is produced based on the findings of the author's master thesis titled "Perception and Interpretation Problems of Contemporary Approaches of the Concept of Jihad" (2019).

1 Istanbul Şehir University, Social Science Institute, Political Science and International Relations, Eposta: abdulhakimallahdad@std.sehir.edu.tr 


\title{
Cihad Kavramının Çağdaş Yaklaşımlarının Algılanma ve Yorumlanma Sorunları
}

Özet

Son yıllarda, İslami disiplinlerde ve özellikle İslam hukukunda temel bir kavram olan cihad kavramı, dünya genelinde en çok tartışılan ve konuşulan terimlerden biri haline dönüşmüştür. Cihad kavramı, İslam tarihi boyunca dini, ilmi, askeri ve politik alanlarda canlılığını her zaman korumuştur ancak 11 Eylül olayından sonra dünya genelinde birçok düşünce kuruluşu, üniversite, akademik kurum, siyasi ve askeri kuruluşlar tarafından cihat kavramı üzerinde muazzam ve dikkat çekici çalışmalar yapılmıştır. Yapılan bu çalışmalarda cihad kavramı farklı şekillerde anlaşılmış, analiz edilmiş, kullanılmış; öyle ki ana anlamından uzak bir şekilde tanımlanmış ve yorumlanmıştır. Dolayısıyla bu çalışma, bu çağdaş yorumlamaları ve yaklaşımları tetkik etmeye çalışmıştır. Son yılların yorumları göz önüne alındığında, dört yaklaşımın yaygın olduğu görülmektedir: indirgemeci, radikal, savunmacı ve İslamofobik yaklaşım. Bu bağlamda, bu çalışma beş ana bölümden oluşmaktadır: ilk bölüm, cihad kavramının İslam'ın temel kaynaklarında (Kur'an ve Sünnet) ve İslami disiplinlerinde kullanımı ele almaktadır. Geri kalan dört bölümde indirgemeci, radikal, savunmacı ve İslamofobik yaklaşımların ana argümanlarına, söylemlerine ve kanıtlarına sırasıyla ve ayrıntılı olarak değinilmektedir.

\section{Anahtar Kelimeler}

Cihad • İslam Hukuku • Savaş • İndirgemeci Yaklaşım • Radikal Yaklaşım •

Savunma Yaklaşımı • İslamofobik Yaklaşım.

\section{مشاكل فهم النهج المعاصرة لمفهوم الجهاد و تفسيرها}

\begin{abstract}
تلخيص
في السنوات الأخيرة, إنّ مفهوم الجهاد الذي هو المفهوم الأساسي في العلوم الثر عية خاصة في الفقه أصبح واحدًا

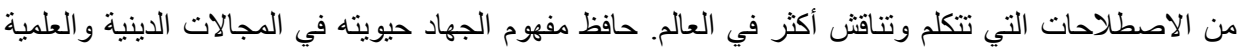

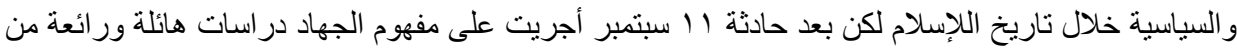

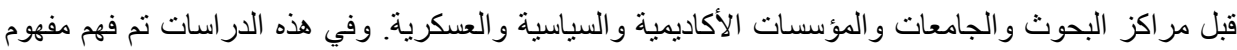

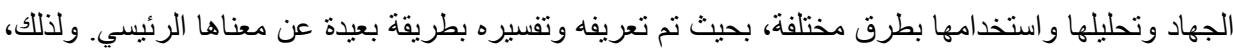

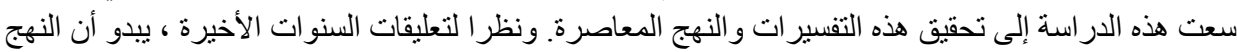

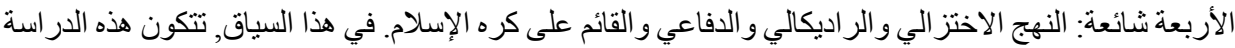

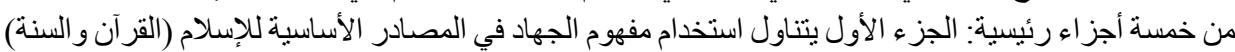

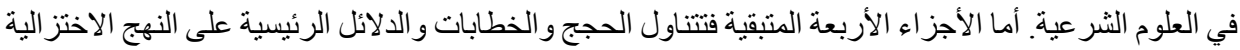

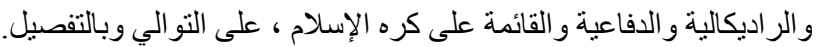
الكلمات المفتاحية
\end{abstract}

الجهاد • الحقوق الإسلامية • النهج الاختز الية •النهج الر اديكالية • النهج الدفاعية • النهج القائمة على كره الإسلام 


\section{Introduction}

Since 9 September 2001, the concept of jihad, one of the essential concepts in Islamic disciplines -particularly in Islamic jurisprudence- has turned into one of the most discussed and debated terms across the globe. The concept of Jihad has always been on the top agenda of politicians and political leaders, university professors and students, think tanks, intellectuals and writes, civil society leaders and activists, media corporations and elites, religious institutions and scholars, armed groups and movements. Moreover, academic studies have rapidly increased in the universities, think tanks and other scholarship organizations on the concept of jihad ever since. It has culminated in the emergence of noticeable and remarkable literature in this field. ${ }^{2}$

Yet in this period, the concept of jihad has been understood, analyzed, defined and interpreted in different meanings by various academicians, writers, politicians, and religious scholars. Some associated jihad with terrorism and regarded it as the ideology of radical armed groups and a new conflict paradigm for the West while some linked it only to self-purification and striving against evils and immoral behaviors. For some jihad meant defensive war, whereas others considered it as the justification of global war, and for others, jihad meant not solely violence and peace but a set of legal, political, military and religious principles. Of course, some series of military and political developments and engagement in the Islamic world besides some unexpected violent, cultural and ideological events that took place in the Western world led to standing on the term of jihad and adopting such kind of approaches and readings. Alongside these developments, one should bear in mind that the concept of jihad has a politico-religious characteristic as well, which itself connotes multi-meanings.

2 Some of the published books in recent decades on Jihad: Firestone, R. (1999). Jihad: The Origin of Holy War in Islam. Oxford, UK: Oxford University Press; Edwards, D. B. (2002). Before Taliban: Genealogies of the Afghan Jihad. California, US: University of California Press; Kepel, G. (2003). Jihad. Paris, France: Editions Gallimard; Cook, D. (2005). Understanding Jihad. California, US: University of California Press; Phares, W. (2005). Future Jihad: Terrorist Strategies Against America. New York, US: Palgrave Macmillan; Bonner, M. (2006). Jihad in Islamic History: Doctrines and Practice. New Jersey, US: Princeton University Press; Marranci, G. (2006). Jihad Beyond Islam. Oxford, UK: Berg Publishers; Roshandel, J., \& Chadha, S. (2006). Jihad and International Security. New York, US: Palgrave Macmillan; Murawiec, L. (2008). The Mind of Jihad. Cambridge, UK: Cambridge University Press; Aaron, D. (2008). In Their Own Words: Voices of Jihad Compilation and Commentary. California, US: RAND Corporation; Phares, W. (2008). The Confrontation: Winning the War against Future Jihad. New York, US: Palgrave Macmillan; Lia, B. (2008). Architect of Global Jihad: The Life of Al Qaeda Strategist Abu Mus'ab Al-Suri. Columbia, US: Columbia University Press; Khan, M. A. (2009). Islamic Jihad: A Legacy of Forced Conversion, Imperialism, and Slavery. New York, US: iUniverse, Inc; Bonney, R. (2010). Jihad From Quran to bin Laden. New York, US: Palgrave Macmillan; Afsaruddin, A. (2013). Striving in the Path of God: Jihad and Martyrdom in Islamic Thought. Oxford, UK: Oxford University Press; Neale, H. S. (2017). Jihad in Pre-modern Sufi Writings. New York, US: Palgrave Macmillan; Spencer, R. (2018). The History of Jihad: From Muhammad to ISIS. New York, US: Bombardier Books. 
In this study, thus, I have attempted to explore and address the contemporary interpretations and approaches to the concept of jihad. Considering the recent years' interpretations and approaches, reflected and articulated in books, journals, articles, and official online websites, this article has broadly categorized modern approaches into four main approaches: reductionist approach, radical approach, defensive approach, and Islamophobic approach. Therewithal, some academicians have roughly made the same classification, to illustrate, Öztürk (2016) has classified contemporary approaches of jihad in the Islamic world into three classes: Radical-traditionalism Approach (political Islamism, in his word), Apologetic Approach, and Contextualist Approach (pp. 128142). Similarly, Qaradawi (2009), chairman of the International Union of Muslim Scholars, has put forward that there are three groups regarding the jihad: a group aspiring elimination of jihad from the life of Muslims, other group declaring global war, and another group keeping the midway and moderate way (pp. 25-27). However, this article's classification has basically influenced by Kavak's (2016) "Fikıh Literatüründe Cihad Hükümleri ve Modern Cihad Yorumları" [Jihad Provisions in the Fiqh Literature and Modern Jihad Interpretations] article. He has categorized modern interpretations of jihad into three classes, as the first class narrowing jihad's jurisprudential meaning; the second class prioritizing the non-jurisprudential meaning of jihad; whereas the third class extending the jurisprudential meaning of jihad (Kavak, 2016, pp. 247-255). What makes this article different is that it has gone from a triple classification to a quadruple classification by adding the Islamophobic approach that previous articles have not touched; besides the article has examined the approaches in more detail.

In this context, the study consists of five main sections with a short conclusion. The first part touches the concept of jihad concisely by taking into account the primary sources of Islam (Qur'an and Sunnah), and classic disciplines. The second section of the study discusses the reductionist approach; the third section addresses the radical approach; the fourth section deals with the defensive approach, and the final section of the study touches the Islamophobic approach.

\section{Jihad in Primary Sources and Early Islamic Disciplines}

Linguistically, jihad is an Arabic word, originating from the word of Jahada (جد), which (in its literal sense) means to make effort, to attempt, and to endeavor (Ma'jam al-Lughat al-Arabiya, 1994, p. 122; Omar, 2008, p. 409). However, the word "jihad" is derived from Jaahada (داج) that in literal meaning denotes severe and extreme endeavoring, scrambling, struggling, striving, and battling against (Haykal, 1996, pp. 38-39; Almaany, 2019). Jihad as a concept in Islamic terminology means to fight and struggle against uncovenanted unbelievers in the path of Allah (Haykal, 1996, p. 40), and spending great effort in defense and expanding of His religion, Islam (Qaradawi, 2009 , p. 65). To define jihad in a broader sense, it is to learn and live according to 
religious orders and to teach it to others, to command goodness and to avoid evil, to communicate Islam, and to fight against external enemies (Özel, 1993, p. 527).

The word jihad holds a remarkable and significant place in the Holy Quran. It is mentioned, with all its derivations and occurrences thirty-two times ${ }^{3}$ in three main meanings: verbal struggle, doing good actions, and fighting against infidels for the sake of Allah. To elaborate on it, verbal struggle refers to communicate Islamic beliefs, rules, values, norms, and to contend and persuade ignorant individuals and unbelievers with knowledge. Doing good actions refers to obey Islamic laws, rules, and norms in every aspect of life, and stay away from all kind of evils and bad actions. Fighting against infidels refers to a military fight against unbelievers in the path of Allah. Nevertheless, most of the Quranic verses are open to warlike interpretation, praising and encouraging fighting in the way of Allah (Haykal, 1996, p. 41).

By glancing at Hadith collections, one can easily conclude that Prophet Muhammad (PBUH) talked about and gave particular importance to jihad. As, Mu'az bin Jabal narrated that Prophet Muhammad (PBUH) said: "The head of the matter is Islam, its pillar is the prayer and its peak is jihad" (Tirmidhi, Hadith Number: 2616). Abu Huraira narrated that the Messenger of Allah was asked, "What is the best deed?" He replied, "To believe in Allah and His Apostle (Muhammad). Again, he (PBUH) was asked, "What is the next (in goodness)? He replied, "To participate in jihad in Allah's Cause" (Sahih al-Bukhari, Hadith Number: 26).

In addition, he (PBUH) widened the scope and meaning of the term of jihad, and used in the multi-meanings, to illustrate: purification of soul/heart from evils, ${ }^{4}$ to communicate Islam and to utter the truth, ${ }^{5}$ fulfillment of Haj Mabrur (for women), ${ }^{6}$ and serving of needy parents ${ }^{7}$ are regarded (also) as an act of jihad. Nonetheless, similar

3 Jihad's different forms mentioned above 32 times in 16 chapters and in 27 verses. Out of this number, six derivations of Jihad are in Makki chapters (An-Nahl 16/110; Al-'Ankabut 29/6,8,69; Luqman 31/15), and remained 26 are in Madani chapters (Al-Baqarah 2/218; Ali 'imran 3/142; An-Nisa 4/95; Al-Maida 5/35; Al-Anfal 8/72,74,75; At-Tawbah 9/16,20,24,41,44,73,81,86,88; Al-Haj 22/78; Al-Furqan 25/52; Muhammad 47/31; Al-Hujurat 49/15; Al-Mumtahanah 60/1; As-Saf 61/11; At-Tahrim 66/9).

4 Fadalah bin "Ubaid narrated that the Messenger of Allah (PBUH) said: "The Mujahid is one who strives against his own soul." (Tirmidhi, Hadith Number: 1621)

5 It was narrated from Anas that the Prophet(PBUH) said: "Strive against the idolators with your wealth, your hands and your tongues." (Sunan an-Nasa'I, Hadith Number: 3096). Abu Sa'eed AlKhudri narrated that the Prophet (PBUH) said: "Indeed, among the greatest types of Jihad is a just statement before a tyrannical ruler." (Tirmidhi, Hadith Number: 2174).

6 Aisha narrated that she asked the Prophet Muhammad (PBUH): "O Allah's Messenger! We consider Jihad as the best deed. Should we not fight in Allah's Cause?" He said, "The best Jihad (for women) is Hajj-Mabrur (i.e. Hajj which is done according to the Prophet's tradition and is accepted by Allah). (Sahih al-Bukhari, Hadith Number: 2784).

7 Abdullah bin 'Amr narrated that a man came to the Prophet (PBUH) asking his permission to take part in Jihad. The Prophet (PBUH) asked him, “Are your parents alive?" He replied in the 
to the Qur'anic verses, the majority of the narrated Hadith prevailingly referred Jihad to military fighting against infidels in the path of Allah. Yet, it should be noted that according to the Quran verses and Hadith, the meaning and conducting of jihad differ concerning its instruments and interlocutors. In terms of the instrument, it can be carried out by tongue/knowledge, property/wealth, and body/weapon; and in terms of interlocutors it can be conducted against unbelievers, one's self, evilness, cruelty, Satan, and hypocrites (Yaran, 2016, pp. 51-52).

\section{The Concept of Jihad in the Classical Islamic Disciplines}

The early Islamic disciplines gave remarkable and well worth attention to jihad, particularly it occupied a significant place in the Hadith, Tafsir, Fiqh, and Sirah literatures. What's more that in these disciplines, the concept of jihad prevailingly is understood and interpreted in a warfare sense, especially the Hadith and Fiqh disciplines equated and used interchangeably the term of jihad with the word of Qitaal and Harb, other Arabic terms for warfare/fighting. These disciplines devoted a special chapter for the subject of Jihad to illustrate the five main Hadith collections - Sahih al-Bukhari, Sahih Muslim, Jami at-Tirmidhi, Sunan Abu Dawud, Sunan an-Nisa'i, Sunan Ibn Majah, and Muwatta- touched thoroughly and comprehensively all regulations, conditions, rules, and norms of warfare, conveyed from the Prophet Muhammad (PBUH) and from his companions, under the title of the Book on Jihad (Kitab al-Jihad), and the Book on Virtues of Jihad (Faza'il al-Jihad).

In a similar way, Fiqh discipline or to say in modern terminology, Islamic Jurisprudence/Law discipline not only addressed regulations and rules relating to warfare but also discussed political affairs and international relations rules and norms under the title of jihad. It is because that Fiqh discipline's scholars developed the law of warfare around the concept of jihad, and defined the term of jihad as the war against unbelievers by body, tongue, and property in the path of Allah (Abu Eid, 2007, 44). Moreover, the four main Islamic jurisprudential schools - Hanafi, Shafi, Maliki, and Hanbali- anonymously divided jihad into two types; Jihad Fard al-Ayn and Jihad Fard al-Kifayah (Abu Eid, 2007, pp. 103-104). Jihad Fard al-Ayn denotes obligatory war, and Jihad Fard al-Kifayah denotes communal obligation war. The former becomes obligatory upon every accountable individual in the event of general mobilization, and a Muslim land attacked by an enemy, it is contemporarily called defensive war. While the latter is an obligatory duty on the Muslim community - if a group of people take part, the rest will be relieved- it is in the normal case that there is no general mobilization and attack on Muslim community (Al-Kasani, 1986, p. 98; An-Nasafi, 2011, p. 369). According to some Muslim jurists, the Muslim ruler is obliged to wage war once in a 
year at least to spread and communicate the religion of Allah to unconquered regions (Ibn Jamaa, 2010, p. 93). Thus, Jihad Fard al-Ayn is a defensive war, and Jihad Fard al-Kifayah is an offensive war.

The above-mentioned explanation and approach of the classic Muslim scholars took away the term of jihad from being just a concept and converted it into doctrine and theory of warfare. To elaborate, following the division of jihad into defensive and offensive, the world was divided into two main poles as well: Dar al-Islam and Dar $a l$-Harb. The former means Home of Islam, all territories that are under the domination of the Islamic state and rules. On the contrary, the latter means Home of War, territories that are not under Islamic state and rules (Türcan, 2016, pp. 285-286). In this sense, the ever-present possibility of the occurrence of war between these two poles existed constantly.

In conclusion, it is understood that the prevailing conception and interpretation of the term Jihad was the jurisprudential interpretation, a war against infidels in the way of Allah to make His religion dominant overall world. Coming to modern times, the term jihad has lost in great dimension its classic interpretation, and loaded up with new elements in its definition. This resulted in various controversial and ambiguous interpretations put forward by both Muslim and non-Muslim scholars, academicians, and thinkers. Therefore, in the following paragraphs, the study will address these new interpretations and approaches.

\section{Contemporary Approaches of the Concept of Jihad}

\section{Reductionist Approach}

In the last decades of the Islamic world, some Muslim thinkers and scholars have attempted to reinterpret the term of jihad by loading new meaning and elements to adjust in accordance with modern circumstances and requirements. From the perspective of these thinkers, the original and essential meaning of the term of jihad is to struggle with interior evils, to purify the soul/heart, to benefit the public, to do good deeds in the path of Allah. Simply, they take out warfare meaning of the term of jihad, rather than reduce it to internal and personal struggle for the sake of Allah.

The reductionist approach, particularly, has become more prevalent and widespread in post-2001. The main characteristics and core arguments of this school are based on the complete denying of warfare connotation of jihad. To illustrate, Ziauddin Sardar, a prominent Muslim professor at City University of London, argued that by looking at Prophet Muhammad's (PBUH) life and Quranic verses, the observed jihad was never associated with war, and it is used as a struggle in the Qur'an, and not linked with war (Sardar, 2016, p. 31). Yet, according to him, Prophet Muhammad (PBUH) during his 
23-years life fought only three battles: Battle of Badr, Battle of Uhud and Battle of Khandaq (p. 31). He states, "when we consider these three main events, we see that every detail is present in the books, but something is missing to understand these wars. That's the idea of strategy. The idea of strategy is at the center of the idea of jihad" (p. 32). In the end, he concludes that jihad is strategic prudence, involving three main elements: ethic, intellectual, and representation (pp. 32-33). Sardar not only attempted to disregard the warfare meaning of jihad but also ignored historical reality regarding the battles of Prophet Muhammad (PBUH), waged and participated. According to AlWaqidi, a prominent Muslim historian, Prophet Muhammad (PBUH) led and took part in 27 battles personally, and organized 47 military expeditions, which himself did not take part (Al-Waqidi, 1989, p. 7).

A similar approach and remark can be seen in Ömer Tuğrul Inançer's discourses. He puts forward: "jihad is not war. The word of jihad comes from the word of jahd (دم)), meaning magniloquent and great effort. The name of many, many efforts is jahd. And the plural of jahd is jihad" (Inançer, 2011; Kavak, 2016, pp. 253-254). These statements of Ömer Tuğrul Inançer's contain a big mistake grammatically. Firstly, jahd does not mean plural efforts, it means making effort, striving, and endeavoring; in fact, the plural of jahd is juhud, not jihad (Arabdict, 2019). At the same time, his reinterpretation of the term of Jihad conflicts with both primary sources of Islam and classical Islamic disciplines and literatures. Relatedly, Abdullah Bin Bayyah and his disciple Hamza Yusuf, co-founder of Zaytuna College, are among the prominent representatives of this approach. From their perspectives, the term jihad does not refer to military doctrine; rather it refers to welfare because Islam is based on four principles: wisdom, welfare, mercy, and justice. According to them, the true jihad is to remember Allah, to serve parents, to read the Quran, and to do good works for humanity (Bayyah \& Yusuf, 2015; Kavak, 2016, 251-252).

The reductionist approach has become more prevalent and widespread among Muslims living in the European countries and the US, as a reaction to both the rise of Islamophobia and the increase of violent attacks done and assumed by some extremist Muslim groups under the banner of Jihad in the West. However, this situation in return carried the concept of jihad to different dimensions, such that it has been defined beyond its context, misrepresented and misinterpreted to the extent that became a title of love stories, to illustrate, My Jihad, a four-episode BBC drama which released in 2014, ${ }^{8}$ and My Accidental Jihad, a book written by Krista Bremer in 2014. ${ }^{9}$ The main topic in both BBC's drama and Bremer's book is a love story of two individuals, showing how they can overcome obstacles, break biases, put aside prejudices, and focus on

8 BBC, (2014). My Jihad. Retrieved from https://www.bbc.co.uk/programmes/p02ty5wz(14.07.2019).

9 Bremer, K. (2014). My Accidental Jihad: A Love Story. North Carolina, US: Algonquin Books. 
common feelings, norms, and customs, and live together. The obvious message here is the struggle against prejudices and biases is jihad.

In addition to this, Ahmed Rehab, Executive Director of Council on American-Islamic Relations, commenced an ad campaign under the title of 'My Jihad' with the slogan of "Taking back Islam from Muslim and anti-Muslim extremists alike" in San Francisco in 2012 (Chowdhury, 2013). The campaign sustained particularly on online websites and social media like Facebook, Tweeter, YouTube, as well on public transports like buses and trains by plastering posters written: "My Jihad is to build friendships across aisle", "My Jihad is thinking out of the box",(Fahim, 2013), "My Jihad is to stay fit despite my busy schedule", "My Jihad is not judging people by their cover", "My Jihad is to march on despite my losing my son" (RNS, 2013). Although the essential target behind this campaign had been to demolish public perception regarding the term of jihad, it distorted and misrepresented the term itself, and reinterpreted in the way that has never been interpreted before, as well it transformed the term of jihad into a simple and ordinary concept.

Some other reductionist scholars give enormous priority to the non-jurisprudential meaning of jihad, although they do not explicitly and completely deny warfare meaning of the term of jihad. In other words, these scholars struggle to disconnect the term of jihad from the warlike interpretation and to reduce it solely to the level of personal/ individual duty and struggle. That is why they frequently use 'greatest jihad' and 'true jihad' expressions in their statements to legitimize, popularize and settle their own type of jihad interpretation in the public. For example, Turkey's Presidency of Religious Affairs asserts: "today, the greatest jihad that Muslims can apply is the jihad against bigotry, poverty, ignorance, corruption, and division” (Din İşleri Yüksek Kurulu, 2015).

The discourses and statements of the reductionist school scholars indicate they have strongly been impressed and influenced by Sufi discipline and tradition. It is wellknown Sufi discipline is interested dominantly in the spiritual and internal life of the human. So in respect of the term jihad, Sufi discipline, like jurisprudential discipline but distinctively, classified jihad into Lesser and Greater Jihad. The former one is a war against unbelievers in the way of Allah, and the latter is struggling with self/soul and interior evils. ${ }^{10}$ In Sufi tradition, human beings' self is the greatest, brutalist, and savage enemy for them; they likened it to "bullshit pig, rabid dog, and Pharaoh" (Öztürk, 2016, p. 104). Since defeating and killing self's desires and pleasures, requires great struggling and fighting, the purification of self is considered as the greatest jihad. Therefore, Sufi tradition stood and made emphasized more on fighting the interior enemy than fighting

10 The most prominent and frequently narrated hadith in Sufi tradition is the following: the Messenger of Allah returned from a battle with his companions, and he said "we have returned from the lesser jihad to the greater jihad". (Al-Bayhaqi, Zuhd, p. 165, Hadith no: 373). 
external enemies. Nowadays, the same approach can be seen in a much more extreme version in the reductionists' statements and discourses.

Lastly, it is worthy to note that reductionists making such inferences regarding the term of jihad by utilizing three main methods. The first method of them is linguistic or word-root analysis, explaining and standing on the dictionary and literal meaning of the term of jihad. The second method is eclectic, reciting the Quranic verses and mentioning the Hadiths that are open to multi-meaning and different interpretations. ${ }^{11}$ The third method is apologetic, to adjust the term of jihad and reinterpret it in accordance with current circumstances and challenges. For example, due to recent decades' violent attacks in Western countries assumed by so-called Islamic groups, native Muslims encountered harsh critiques, as well faced various discrimination. Therefore, some Muslim scholars and thinkers needed to respond to the critiques, and present Islam as a religion conforming to liberal and democratic values such as peace, toleration, wisdom, mercy, justice and so forth. In short, the political, social and educational background has made a big role in the shaping of reductionists' minds.

\section{Global/Radical Jihad Approach}

It is common knowledge that the Islamic world has been subjected to military, political and cultural pressure and intervention of the West during the last three centuries. Particularly in the first half of the twentieth century, the abolition of the Caliphate, dismantling of Islamic law, and the establishment of secular and authoritarian states stimulated and mobilized intellectual Muslims and scholars. Among them, some wanted to respond to this horrible situation through educational and political ways, while others turned to armed struggle to put an end once (for all). Those who turned to the armed struggle started the war under the banner of jihad against both the states that had established military bases and deployed their military in the Muslim countries and against the states who invited and allowed them. The Afghan jihad is a typical example (of such case). It should be noted that most of the scholars in the armed movement remained committed to the classical conception and understanding of jihad while a minority group of scholars took the term of jihad to a different dimension. In particular, the US invasion of Afghanistan and Iraq in 2001 and 2003 respectively led to the acceleration of this approach. Today, one can call this school of thought as a radical or post-1990 approach or global jihad approach.

The core argument of global jihad's scholars is that today jihad/warfare is an obligatory duty upon every eligible Muslim both in the East and in the West; thus, every eligible Muslim should do jihad by any means that he/she accessing against their states, the invaders and unbelievers. According to Kavak (2016), the advocates of the global

11 Like the following verses: al-Ankabut 29/6-8-69, al-Furkan 25/52, an-Nahl 16/110. 
jihad approach have presented a new understanding of jihad by enlarging the meaning of jihad and interpreting it beyond its classic jurisprudential scope (p. 255).

The advocates of global jihad ${ }^{12}$ substantiate their assertions by stating that today's Muslim countries are ruled by apostates, oppressors, faithless, deviant, devious, heretic, corrupt politicians; and the state itself is governed by secular and anti-Islamic laws, making it the heretic and degenerated state (Faraj, 1981, p. 12; Al-Filistinli, no date, pp. 82-85). In this case, they conclude, toppling of these degenerated states, and restoring of an Islamic state and caliphate is an obligatory duty/Jihad Fard al-Ayn on every Muslim (Faraj, 1981, pp. 7-9; Al-Filistinli, no date, p. 85). Anwar al-Awlaki, one of the most important pioneers of global Jihad school, implies to this point with the following words:

"Jihad is the greatest deed in Islam and the salvation of the Ummah is in practicing it. In times like these, when Muslim lands are occupied by the kuffar [infidels], when the jails of tyrants are full of Muslim POWs, when the rule of the law of Allah is absent from this world and when Islam is being attacked to uproot it, Jihad becomes obligatory on every Muslim. Jihad must be practiced by the child even if the parents refuse, by the wife even if the husband objects and by the one indebt even if the lender disagrees." (Al-Awlaki, no date, p. 1).

Yet, according to Awlaki, taking weapons and going to the battlefield is not the only way to do jihad; whereas, there are 44 ways an eligible Muslim can fulfill his/her obligatory duty and join to the caravan of Mujahedeen. All of the ways that he counted are associated with the physical fight in one way or another..$^{13}$ The first theoretical ground

12 The prominent representative of global jihad approach are: Muhammad Abd al-Salam Faraj, Abu Musab al-Zarqawi, Anwar al-Awlaki, Abu Mus'ab as-Suri, Osama bin Laden, Ayman al-Zawahiri, Abu Bakr Al-Baghdadi, Abu Qatada al-Filistini, Abu Muhammad al-Maqdisi, Hani Mohammed Yusuf al-Siba'i, Yusuf al-Uyayri, and so forth.

13 Awlaki's 44 ways to support jihad are 1. Having the right intention, 2. Praying to Allah to award you with martyrdom, 3. Jihad with your wealth, 4. Fundraising for the mujahideen, 5. Financing a Mujahid, 6. Taking care of the family of a Mujahid, 7. Sponsoring the family of a shaheed, 8. Sponsoring the families of the prisoners of war, 9. Paying your zakah to the mujahideen, 10. Contributing to the medical needs of the mujahideen, 11. Providing Moral support and encouragement for the mujahideen, 12. Defending the mujahideen and standing up for them, 13. Fighting the lies of the Western Media, 14. Exposing the hypocrites, 15. Encouraging others to fight Jihad, 16. Protecting the mujahideen and preserving their secrets, 17. Praying for the mujahideen, 18. Following the news of Jihad and spreading it, 19. Spreading the writings of the mujahideen and their scholars, 20. The issuance of fatwas supporting the mujahideen, 21. Providing the scholars and Imams with information and news about the mujahideen, 22. Physical fitness, 23. Arms training, 24. First aid training, 25. Learning the fiqh of Jihad, 26. Protecting the mujahideen and supporting them, 27. Developing the Aqeedah of Walaa' and Baraa', 28. Fulfilling our responsibilities towards the Muslim POW, 29. WWW Jihad, 30. Raising our children on the love of Jihad and the mujahideen, 31. Avoiding the life of luxury, 32. Learning skills that would benefit the mujahideen, 33. Joining groups that work for Jihad, 34. Spiritual preparation, 35. Guiding others to the scholars of truth, 36. Preparing for Hijrah, 37. Giving naseehah to the mujahideen, 38. Studying the hadiths 
and religious framework of global jihad are based on the document of 'Declaration of War against the Americans Occupying the Land of the Two Holy Places' published in 1998, known as "the Osama Bin Laden Fatwa" as well. The document was signed by five different jihadi groups' leaders: Usama bin Ladin, leader of Al-Qaeda; Ayman al-Zawahiri, leader of the Jihad Group in Egypt; Abu Yasir Rifa'i Ahmad Taha, leader of Egyptian Islamic Group; Shaykh Mir Hamzah, secretary of the Jamiat al-Ulema-i Pakistan; Fazlur Rahman, leader of the Jihad Movement in Bangladesh. These leaders declared the following fatwa -religious order- to all Muslims:

"The ruling to kill the Americans and their allies -- civilians and military -- is an individual duty for every Muslim who can do it in any country in which it is possible to do it, in order to liberate the al-Aqsa Mosque and the holy mosque [Mecca] from their grip, and in order for their armies to move out of all the lands of Islam, defeated and unable to threaten any Muslim. This is in accordance with the words of Almighty Allah, "and fight the pagans all together as they fight you all together," and "fight them until there is no more tumult or oppression, and there prevail justice and faith in Allah" (World Islamic Front Declaration 1998).

The audience of this document is the US and its allies' citizens. Also, the distinctive character of the document is a requirement of fighting against Americans and its allies' citizens inside or outside their territories without discrimination of combatant and noncombatant, civilian people and military forces. In this context, three years later, Yusuf al-Uyayri, one of the famous scholars and former leader of al-Qaeda in the Arabian Peninsula, justifies the killing of American civilians inside their territory in the following words:

"Due there is no [peace] covenant with the US, it is a Dar al-Harb/territory of war. In essence, Muslims are permitted to attach any kind of casualty and harm to the territory of war, as its citizens'blood, property, and women are halal/permitted to Muslims... they become haram/unpermitted when there be a treaty" (Al-Uyayri, 2001, p. 7).

Global Jihad's scholars have undoubtedly been influenced by classical jurists' scholars, in the sense using, to a great extent, jurisprudential terms, concepts, and shreds of evidence in substantiating their actions and activities. However, they fail to act in accordance with current circumstances and conditions that Muslims coping with, as well as ascertaining and identifying ways, methods, actions and activities that cause great benefits to all Muslims than its damage.

To conclude, albeit a lot of conflictual ideas and thoughts exist among armed and unarmed Islamic groups, yet four major differences putting global Jihad in a distinct

of fitan, 39. Exposing Pharaoh and his magicians, 40. Nasheeds, 41. Boycotting the economy of the enemy, 42. Learning Arabic, 43. Translating Jihad literature into other languages, 44. Teaching others about the characteristics of al Ta'ifah al Mansoorah. 
place: firstly, from viewpoint of the global Jihad's scholars, today doing jihad is an obligatory duty/Fard al-Ayn on every eligible Muslim. Secondly, establishing an Islamic state and restoring the caliphate is achievable through military struggle; thirdly for achieving the goal and in the last resort killing of civilians is allowed; finally attacking American and its allies' citizens and soldiers in every corner of the globe is permitted.

\section{Defensive Approach}

In the last century, the defensive approach has become a dominant approach among contemporary interpretations of the concept of jihad; even one can contend that it has turned into a mainstream approach in the Islamic world. The main argument of this school is the Quran and Sunnah have solely permitted defensive war, as all the conducted wars of the Prophet Muhammad's (PBUH) are defensive in its essence. Thus, the just and permitted war in Islam is the defensive war.

The advocates and representatives of the defensive approach consist of religious scholars, academicians, politicians, and ordinary people. One of first modern and at the same time prominent figures of this approach is Sir Sayyid Ahmad Khan, who asserted, "Islam does not allow wars other than self-defense war. Islam permits war in two cases: a) when non-Muslims invade the land of Muslim not because of to conquer it but because of their hostility towards Islam to destroy it; $b$ ) in a country where Muslims are not allowed to live in peace and do not worship freely" (cited by Kavak, 2003, p. 160). Sir Ahmad Khan bound legitimation of war/jihad to two conditions: infidels' invasion of a Muslim land on the intention to attack Islam, and restriction/lack of the freedom of religion for Muslims.

Ahmad Khan's thoughts and discourses have had a huge impact on the next Muslim generations. To illustrate, Muhammad Abduh, Rashid Reza, and Muhammad Asad shared similar sentiments and ideas with Ahmad Khan, asserting Islam has permitted defensive war, and the Messenger of Allah interred into war against disbelievers only in the case of self-defense (Öztürk, 2016, pp. 137-138). In addition, Saffet Köse contended that jihad has a defensive character by taking into consideration the verses of jihad in the Holy Quran, and the conditions of the era of the Prophet Muhammad (PBUH); yet he regards five reasons as the justification for waging a war: legitimate defense, violation of peace treaties, killing of envoys, collaboration with enemy, to save/help Muslims who exposed to violence and torture because of their beliefs in non-Muslim territory (Köse, 2007, pp. 59-63).

One important point to be mentioned here, for a better understanding of the issue, is Islamic war law. The justifiable reasons to wage war on non-Muslims is an arguable and debatable topic among Muslim jurists. The classic Muslim jurists separated into two groups in this regard, one group of scholars regarded the justifiable reasons for the war 
in Islam the unbelievers' waging war against Muslims, and another group of scholars regarded their disbelief and blasphemy as a cause of war (Özel, 1993, p. 528). The Quranic verses that ordering war can be classified into main categories: restrained and unrestrained, or to say conditional and absolute verses. The conditional verses explain the reasons for waging of war on unbelievers, to illustrate, Al-Baqarah 2/190-194; An-Nisa 4/75-76; Al-Anfal 8/38-39, 56-58; At-Tawbah 9/12-13. While unrestrained verses do not mention the reasons, they are mentioned in the absolute statement, to say Al-Baqarah 2/244; At-Tawbah 9/5, 29. Different opinions and thoughts among classic and modern Muslim scholars and intellectuals on whether Islamic sources have merely permitted defensive war or offensive war stems from the nature of the above-mentioned verses.

Moreover, Muslim jurists argued on the nature of Prophet Muhammad's (PBUH) wars whether they were defensive or offensive. For example, Mahmud Shaltut, Wahba az-Zuhayli, Omar Ahmad Farjani arguing the Prophet Muhammad's (PBUH) wars were defensive; while Muhammad Hasan, Ramazan al-Buti, Yasin Suwaid and so forth scholars contending that the Prophet Muhammad's (PBUH) wars were both defensive and offensive (Haykal, 1996, pp. 511-512. According to Talip Türcan, most of the Muslim scholars believed in defense and offense nature of the wars, organized by the Prophet Muhammad's (PBUH) wars (Türcan, 2016, p. 291).

To understand the Prophet Muhammad's (PBUH) wars, one should make clear the meaning of defensive and offensive war. The dispute between scholars stems from the use of defensive and offensive war concepts in different meanings. To elaborate, in military terms offensive war means to initiate the war by going and attacking the opponent's place and territory. While defensive war, as a military term, means counterattacking, waiting for the opponent to commence war, in return responding to the war initiator to protect one's self and land. However, in political and legal/law language, if the initiator of war commenced war for justifiable reasons, this war can be called a defensive war from the side of the initiator. For example, when the US attacked Afghanistan and Iraq in 2001 and 2003 respectively, the US announced it defensive war due to protect itself from any possible threat; whereas the states of both countries did not attach any kind of damage to the US. From this point of view, if we talk about the wars of Prophet Muhammad (PBUH) in military language, all the battles he personally joined or organized any expedition are offensive, except the battle of Uhud and the battle of Khandaq. The battle of Uhud and Khandaq are only two battles that the Meccan unbelievers initiated the attack on Muslims, and Muslims took a defensive position. Other than these two battles, it was the Prophet Muhammad (PBUH) who initiated the attack on his opponents, as did in the battle of Khaybar, the battle of Mu'tah, the battle of Hunayn, the battle of Tabouk, and so forth battles. Besides, the Prophet Muhammad (PBUH) launched dozens military expeditions during his lifetime, to illustrate the 
expedition of Hamza ibn 'Abdul-Muttalib, the expedition of Ubaydah ibn al-Harith, the expedition of Umar ibn al-Khatab, the expedition of Abu Bakr As-Siddiq, the expedition of Amr ibn al-As, the expedition of Usama bin Zayd, and so forth expeditions. Thus, it is unfair and beyond historical reality to assert all the wars of Prophet Muhammad (PBUH) were defensive in essence. Definitely, the wars and expeditions he conducted were based on justifiable reasons, but in the military sense, most of them were offensive warfare. Besides, if the wars of Prophet Muhammad (PBUH) had been defensive, he could not expand Islamic territory in a very short period. As one the main advantage of offensive war is enabling to expand one's political domination and to gain territory. Of course, the Prophet Muhammad (PBUH) did not engage in war on that intention, however, he engaged in the intention to spread the religion of Islam to get Allah's consent. The proper method to resolve this issue is to put it in this way, most of the Prophet Muhammad's (PBUH) wars were defensive in principle and politico-legal terms, but offensive in operation and military sense.

The same inference and conclusion are valid for Four Rightly Guided Caliphs: Abu Bakr, Umar, Uthman ibn Affan, and Ali. During their 30-years, Persian Empire collapsed and the Roman Empire lost its Holy City, Jerusalem; hence Islam expanded from Persia to North Africa in a short time. Four Rightly Guided Caliphs countered and interred into very severe battles with unbelievers on the intention to spread Islam and to glorify the religion of Allah. In this sense, historical records demonstrate that both defensive and offensive warfare have legitimacy in Islam. One should note, the warfare that is not for the sake of Allah, cannot be called jihad. The offensive jihad/war is permitted only to spread Islam, and to glorify the religion of Allah.

\section{Islamophobic Approach}

The approaches mentioned above have been generally common among Muslim scholars, thinkers, and intellectuals. However, a new understanding of jihad emerged in the West, especially after 2001, which can be called the Islamophobic approach. The core interpretation and assertion of this approach is that jihad denotes violence, terror, and warfare. In other words, the advocates of the approach regard the term of jihad as the source of terrorist acts and violent attacks.

This new reinterpretation of the term of jihad in the West has become popular and prevalent mostly among racist groups, nationalist individuals, far-right political parties, and biased academicians and intellectuals. For example, according to Daniel Pipes, the president of the Middle East Forum, jihad is "holy war", and "today, jihad is the world's foremost source of terrorism, inspiring a worldwide campaign of violence by selfproclaimed jihadist groups" (Pipes, 2002). Daniel Pipes not only associated jihad with the violence but also deemed it as the source of terrorism. Similarly, another prominent 
representative of this approach is Geert Wilders, a very controversial figure in Europe; he is the founder of Party for Freedom, a far-right party in the Netherlands, and one of the pioneers of the propagators of anti-Islamic speech and movements in Europe. From his point of view, not only jihad is a terrorist act but also Islam in its essence is a "violence", "honor killing", and "terror religion" (Wilders, 2013; Party for Freedom, 2018). One can infer from the above statement of Geert Wilders that he by attacking Islam implicitly implying that one who believed in Islam is the potential terrorist, and a threat for the rest of the world.

David wood, an American evangelical missionary, by sharing the same view with Geert Wilders, contends that the Prophet of Islam's ultimate aim was to conquer the world through terror, as he stating, "The terror was the favorite tactic of the founder of Islam" (Wood, 2017). The attention-grabbing point in David Wood's statement is that instead of the word of jihad, he used the word of terror to demonstrate that terrorist acts begun with the Prophet Muhammad (PBUH). One can see ex-Muslims among the prominent representatives and supporters of the Islamophobic approach. To illustrate, Khan articulates his feelings and thoughts regarding the jihad as follows: "Prophet Muhammad had established three major models of Jihadi actions: use of violence for the propagation of Islam, Islamic imperialism, and Islamic slavery" (Khan, 2009, p. 5). Actually, Khan tried to utter Muslim compelled non-Muslim to conversion to Islam, exploited their sources and assimilated from their culture, and legalized the enslavement under the name of Islamic jihad.

Without a doubt, the attempt to re-conceptualize and reinterpret the term of jihad in the way to equate it with the concept of terrorism and then to claim Islam's primary sources, Quran and Sunnah, encouraging and promoting violence and terrorist acts is far from scholarship and academic domain. In fact, in the twentieth century, the totalitarian regimes like communism and fascism were the main rival and enemy of the Western states, and in late twenty century in particular in the 1990s onwards the militant Muslim groups, and those who struggled in the political arena to encourage establishment of the state on Islamic values in the Muslim countries were perceived a threat by the West, in particular the US. David Aeron by indicating to this point states that "in the 20th century, the West confronted three totalitarian revolutionary movements: Nazism, Communism, and Fascism. Now the world is under assault from a fourth such movement whose members operate under many labels -Islamic terrorists or extremists, Salaf militants, Islamo-Fascists, and jihadis, to name a few" (Aeron, 2008, p. 1). However, after the September 11 incident and the subsequent armed attacks in Madrid and London, Islam itself has been deemed as a potential threat to the Western countries. That is why the West launched a military, political and cultural war against Islamic sources in academia and its believers in the battleground. 
As it is known, intellectual war is more acrimonious, harsh and more long-lasting than military war. Military war may end within a few months and years, but the traces of the intellectual war last for years. The intellectual war launched to determine the essential causes of the attacks so that the source of the problem could be found and eliminated; in this case, arguable and controversial opinions and sentiments were expressed by the academicians and intellectuals. In this context, some academicians saw the root of causes in the false foreign policy of the US pursued in the Islamic world, and some attributed to the perpetrators' psychological and economic situation. While, some have said that the problem itself is rooted in the main sources of Islam, hence they must be tackled. Spencer is among those who deem the root of the problem in Islamic primary sources, as he states:

"There is no period since the beginning of Islam that was characterized by large-scale peaceful coexistence between Muslims and non-Muslims. There was no time when mainstream and dominant Islamic authorities taught the equality of non-Muslims with Muslims or the obsolescence of jihad warfare. There was no Era of Good Feeling, no Golden Age of Tolerance, no Paradise of Proto-Multiculturalism. There has always been, with virtually no interruption, jihad." (Spencer, 2018, p. 1).

What he meant by jihad is warfare, oppression, violence, and terror. It can be easily understood from his book's title -The History of Jihad: From Muhammad to ISIS- that in reality, he implies by the word of jihad to the terror and violence begun with the Prophet Muhammad (PBUH) and continuing up to now. Devin Springer et al (2008, p. 1) argue Islamic radicalism and violent jihad have given birth to terrorism. In line with this approach, Ibn Warraq, a former Muslim and the founder of Institute for the Secularisation of Islamic Society, goes against those who arguing terrorism not stem from Islamic primary sources, instead Ibn Warraq asserting that:

"To understand the behavior of Islamic terrorists, to make sense of their motives, we must take their beliefs seriously. The acts of ISIS or the Taliban or any other jihādist group are not random acts of violence by a mob of psychopathic, sexually frustrated, impoverished vandals, but carefully and strategically planned operations that are part of a long campaign by educated, affluent Muslims who wish to bring about the establishment of an Islamic state based on the Shari 'a-the Islamic Holy Law, derived from the Koran, that is the very word of God, and from the Sunna of the Prophet and the Traditions (ahädìth, pl. of hadīth), which are the sayings and doings of Muhammad and his companions" (Ibn Warraq, 2017, p. 1).

In a short period, this intellectual war resulted in emerging and constructing of new concepts such as Islamic terrorism, Islamist terrorism, radical Islamic terrorism, Islamic fundamentalism, Islamic extremism, Islamic radicalism, Islamic Jihadism, Islamic political violence, and so forth. Definitely, these concepts explicitly and directly turned 
Islam into the target, such that by putting the word of "Islamic" in front of the violence words implying that Islam inherently contains within itself terrorist acts, violence and oppression. Meanwhile, numerous books and articles have been written and published carrying the above concepts on its main title. ${ }^{14}$ In addition, as a result of this intellectual struggle, nowadays the above concepts and Jihadism concept have become equivalent to terrorism, in other words, these concepts have been using interchangeably in the academia, mass media, and political arena. It is understandable to some degree that critique of Islam without any hesitation have utilized these concepts in their daily life deliberately, but what is odd that Muslim academicians, intellectuals, thinkers, writers, and politicians have used these concepts in their daily speech and their books and articles.

It is worthy to note that anti-Islamic polemicists' labeling of Islam as a terrorist religion is not new. By glancing a short look at history's pages, it is highly possible to encounter this kind of pejorative labeling of Islam and Muslims throughout history. In Medieval ages, Islam was portrayed, in the West, as a "deviant and irrational" religion, and Muslims as a "barbarian, despot, mindless, irrational, lustful, bloodthirsty, and so forth" people (Kalın, 2016, p. 115). Hence, one can conclude then that equating and associating the term of jihad with terrorism is the continuation of a tradition and the product of biased and ideological initiative.

14 To name some of these studies: O'balance, E. (1996). Islamic Fundamentalist Terrorism, 1979-95: The Iranian Connection. New York, US: Palgrave Macmillan; Euben, R. L. (1999). Enemy in the Mirror: Islamic fundamentalism and the limits of modern rationalism. New Jersey, US: Princeton University Press; Emerson, S. (2003). American Jihad: The Terrorists Living Among Us. New York, US: Simon and Schuster; Edwards, M. (2005). Islamic Fundamentalism since 1945 (Making of the Contemporary World). Abingdon, UK: Routledge; Phares, W. (2007). The War of Ideas: Jihadism against Democracy. New York, US: Palgrave Macmillan; Perry, M., \& Negrin, H. E. (Eds.) (2008). The Theory and Practice of Islamic Terrorism: An Anthology. New York, US: Palgrave Macmillan; Springer, D. R., et al (2008). Islamic Radicalism and Global Jihad. Washington, D.C., US: George Town University Press; Falk, A. (2008). Islamic Terror: Conscious and Unconscious Motives. New York, US: Praeger; Sookhdeo, P. (2009). Understanding Islamist Terrorism: the Islamic Doctrine of War. Hong Kong, China: Isaac Publishing; Brachman, J. M. (2009). Global Jihadism: Theory and Practice. Abingdon, UK: Routledge; Kepel, G. (2017). Terror in France: The Rise of Jihad in the West. New Jersey, US: Princeton University Press; Ibn Warraq (2017). The Islam in Islamic Terrorism: The Importance of Beliefs, Ideas, and Ideology. London, UK: New English Review Press; Mohanty, N. (2018). Jihadism: Past and Present. Maryland, US: Lexington Books; Nesser, P. (2018). Islamist Terrorism in Europe. London, UK: C. Hurst \& Co; Fredholm, M. (2018). Transnational Organized Crime and Jihadist Terrorism: Russian-Speaking Networks in Western Europe. Abingdon, UK: Routledge; Richards, A. (2019). Jihadist Terror: New Threats, New Responses. London, UK: Bloomsbury Publishing; Rinehart, C. S. (2019). Sexual Jihad: The Role of Islam in Female Terrorism. Maryland, US: Lexington Books. 


\section{Conclusion}

This study has aimed to deal with the contemporary conceptions and interpretations of the term of jihad. The study has initially touched the early classic period scholars' interpretation, afterward stood on modern conceptions that classified into four main categories: reductionist, radical, defensive, and Islamophobic approaches. The classical Islamic disciplines defined jihad, in narrow terms, as fighting in the way of Allah, and in broad terms defined it as a struggle to defend, spread, and glorify the religion of Allah, as well to obey and establish orders of Allah across the globe either by soft or hard methods and instruments. Coming to the modern era, the classical understanding of jihad has been distorted, misrepresented, and defined beyond its scholarship context. Such that the reductionists denied warfare meaning of it, and attributed it only to making effort, doing a good deed and serving parents and needy people. The radical groups regarded jihad as an obligatory duty that every eligible Muslim should perform it by any accessible instruments. Although they accept the classical understanding of jihad, the deviant point is that they deem legitimate the indiscriminate attacking enemy. On the other hand, the defensive school restricted the scope of jihad to the defense of land and body on the event of attacking by an enemy, and contended that Islam's primary sources permitted solely defensive war/jihad. Contrary to all of these approaches, the Islamophobic School has defined the concept of jihad as violence, terrorist acts, oppression, and holy war. According to this approach, the jihad functioned as a theory of imperialism, colonialism, forced conversion, and enslavement of non-Muslims.

In the contemporary world, most Muslims and non-Muslims scholars, academicians, thinkers, politicians and civils are involved in one of these four mentioned-approaches. Still, there scholars and intellectuals who sustaining and holding the classical understanding with slight different discourses and nuances, to illustrate, Abul A'la Mawdudi and Hasan al-Banna can be considered among these scholars, albeit the bulk of academicians and politicians put them in the category of the radical approach. One can naturally ask why the article, unlike most of the other articles, has not placed these scholars into the radical approach. The answer to this question lies down in defining the word of "radical", in other words, based on which criteria and measures one defines the word "radical". The article has assessed the radical approach based on Islam's primary sources and classic disciplines, and found that advocates of the above-mentioned radical approach went astray from the classic mainstream line by accepting the global war as a jihad, and legitimizing the indiscriminate attacks. While, Mawdudi and Hasan al-Banna both scholars did not utter and support such kind of thoughts in their articles, books, and speeches. Moreover, both scholars did not advocate, contrary to today's radical movements like al-Qaeda and ISIS, any violent attack to be done among civilians either in Muslim countries or in Western countries. Instead, Mawdudi and Hasan al-Banna not only held and regarded the peaceful means the lawful, effective, successful and 
proper ways for restoring of an Islamic state, and clearing out of Muslim countries from external and internal evils and devils, but also they, in their whole lives, struggled to implement and spread their thoughts, ideas, principles through social, political and educational revolution.

The tangible indicator for the seeing of this reality is Hasan al-Banna's Muslim Brotherhood organization that founded for bringing social, educational, and political changes in the society and state. In this sense, he did not set any tiny-armed group or organization, and not attend to any violent groups. Of course, the later generations of Muslim Brotherhood split into two main camps, one camp came close to violent attempts, the other camp supported peaceful methods like participating in elections. Since this separation occurred after the death of Hasan al-Banna, hence he cannot be found responsible for any of them. In a similar way, Mawdudi followed the path of Hasan and founded a political party, Jamat al-Islami in Pakistan, participating in the election and struggling to gain power through a peaceful way, not through the military way. Thus, these realities indicating that these scholars were not radical, as their opponents asserting and attaching to them the stigma of radical.

Before to put a final point, one should take into account that human beings do not observe and look at the outside world as it is, but everybody looks through an ideology, theory, paradigm, worldview, briefly through a set of beliefs and ideas in one way or another way. Besides, they utilize some concepts for understanding, analyzing, describing, explaining, and interpreting what they have read, listened, observed and experienced. In this term, concepts compose building stones of intellectual and methodological processes. That is the reason that every academic discipline has specific terms and concepts, composing a particular language for that discipline. In other words, one can separate one discipline from another discipline by its featured terms and concepts. Therefore, to contemplate and speak correctly and accurately within the framework and scope of the discipline, it is essential to understand a concept as its discipline conceptualized and defined it; otherwise, it will lead to the confusion of concept.

It is well known that every word, in general, contains two types of meaning: literal meaning, and terminological meaning. The literal meaning is either natural or determined by linguists; whereas, the terminological meaning is given by particular academic discipline, which its meaning varying from discipline to discipline. To illustrate, the word 'state' literally possesses many different meanings to say situation, express, say, declare and so forth; while as a term in political science discipline it denotes a form of polity or a political entity that has specific characteristics. In the same way, the meaning of jihad as a word and as a concept within a discipline differ to a large extent. 
The source of the problem lies in confusing and mixing the literal and terminological meaning of the word of jihad. In this context, this study has explored that the abovementioned approaches' advocates either prioritized literal meaning and ignored the terminological meaning and historical reality, or redefined it without considering the classic literatures, or interpreted and defined totally beyond its scholarship context. These features are seen in the contemporary approaches and interpretations of jihad. Those who attempted to interpret and redefine the concept of jihad in accordance with today's political, economic, social and cultural conditions have unfortunately distorted, falsified, misused, misrepresented, and made ambiguous the concept of jihad. The tangible indication is that nowadays one can hear, from every mind and mouth, different definitions of jihad. Therefore, to avoid falling into the conceptual confusion, the reasonable method is to touch Islam's primary sources and classic disciplines and literatures with a holistic approach and self-confidence, and not an eclectic and apologist approach.

\section{Acknowledgement}

It is my pleasure to offer my sincere thanks to Assoc. Prof. Özgür KAVAK, and Asst. Prof. Ahmet OKUMUŞ for their contributions and help during the writing of this study; as well I would like to thank my colleagues Muhammed Mustafa Bilgili, and 'Ubaid Azhar Zaman for their beneficial comments.

\section{References}

Al-Bukhari, M. I. (2002). Sahihi al-Bukhari. Beirut, Lebanon: Dar Ibn Kasir.

Almaany. Jihad (2019). In Almaany.com. Retrieved from

https://www.almaany.com/ar/dict/ar-ar/\%D8\%AC\%D9\%87\%D8\%A7\%D8\%AF/ (06.07.2019).

Abu Eid, A. K. (2007). Al-Alaqat al-Duwaliyyah fi-Fiqh al-Islami [International Relations in Islamic Law].

Amman, Jordan: Dar al-Nafais.

Al-Kasani, A. (1986). Bada'i es-Sana'i fi Tertib eş-Şera'i [Unseen Artistry in the Arrangement of the Religious-Legal Regulations]. Beirut, Lebanon: Dar al-Kutub al-Ilmiyye.

An-Nasafi, A. A. (2011). Kanz ad-Daqa'iq [The Treasure of Minutes]. Beirut, Lebanon: Dar alBaşair al-Islamiyya.

Al-Waqidi, A. A. (1989). Kitab Al-Maghazi. Beirut, Lebanon: Dar al-'Alami.

Arabdic. Jahd (2019). In Arabdic.com. Retrieved from

https://www.arabdict.com/en/\%D8\%B9\%D8\%B1\%D8\%A8\%D9\%8A-\%D8\%B9\%D8\%B1\%D8 \%A8\%D9\%8A/\%D8\%AC\%D9\%87\%D8\%AF (10.07.2019). 
Al-Awlaki, A. (no date). 44 Ways to Support Jihad. Retrieved from

https://ebooks.worldofislam.info/ebooks/Jihad/Anwar_Al_Awlaki_44 Ways To_Support_Jihad. pdf (19.07.2019).

Al-Filistinli, A. Q. (no date). Al-Jihad wa Al-Ijtihad [Jihad and Judicial Opinion]. Retrieved from https://www.cia.gov/library/abbottabadcompound/BA/BAC8CB3E99948203B6EF401549A0C AEDjihad.pdf (25.07.2019).

Al-Uyayri, Y. (2001). Haqiqat al-Harab al-Salibiyyah al-Jadid [The Truth of New Crusader Wars]. Minber at-Tawhid wa al-Jihad Retrieved from https://archive.org/details/setsuko_6 (15.07.2019).

Aeron, D. (2008). In Their Own Words: Voices of Jihad: Compilation and Commentary. California, US: Rand Cooperation.

Bayyah, B, A., \& Yusuf, H. [Rismultimedia] (2015, January 9). RISTalks: Shaykh Abdallah Bin Bayyah - "Fiqh of Reality". Retrieved from https://www.youtube.com/watch?v=rgBwGmfXi5E (10.07.2019).

BBC, (2014). My Jihad. Retrieved from https://www.bbc.co.uk/programmes/p02ty5wz (14.07.2019).

Bremer, K. (2014). My Accidental Jihad: A Love Story. North Carolina, US: Algonquin Books.

Chowdhury, M. (2013). Through Ad Campaign, Muslim Activists Want To Redefine 'Jihad'. National Public Radio. Retrieved from https://www.npr.org/sections/thetwo-way/2013/01/30/170694966/ through-ad-campaign-muslim-activists-want-to-redefine-jihad (14.07.2019).

Din İşleri Yüksek Kurulu (2015). DAEŞ'in Temel Felsefesi ve Dini Referansları [ISIS Basic Philosophy and Religious References]. Retrieved from https://dosya.diyanet.gov.tr/DIYKDosya/ YayinDosya/783591fa-9f88-41b7-ab2f-3d0fa114f500.pdf

Fahim, S. (2013). \#MyJihad - The 'Struggle' to Reclaim Islam. Muslim Matters. Retrieved from https://muslimmatters.org/2013/03/11/myjihad-the-struggle-to-reclaim-islam/ (14.07.2019).

Faraj, M. A. (1981). Al-Farida al-Ghaibah [The Absent Obligation]. Retrieved from https:// archive.org/details/faredah.ghaebah (15.07.2019).

Haykal, M, H. (1996). Al-Jihad wa al-Qital Fi al-Siyasat al-Shar'iah [Jihad and Warfare in Legitimate Politics].

Beirut, Lebanon: Dar al-Bayareq.

Ibn Warraq (2017). The Islam in Islamic Terrorism: The Importance of Beliefs, Ideas, and Ideology. London, UK: New English Review Press.

Inançer, Ö, T. [Canberkhan] (2011, August 15). Pazar yerine bomba atmak kancıklıktır. [Throwing Bombs in Bazaar is meanness] [Ömer Tuğrul İnançer]. Retrieved from https://www.youtube. com/watch?v=3H i13OXXZ8 (10.07.2019).

Ibn Jamaa, B. (2010). Adl'e Boyun Eğmek, Ehl-i İslâm'ın Yönetimi İçin Hükümler [Submitting to the Judiciary, Provisions for the Administration of People of Islam]. (Ö, Kavak, Trans.) Istanbul, Turkey: Klasik Yayınları.

Kavak, Ö. (2003). Modernizmin Dönüştürücü Etkisi: Seyyid Ahmed Han Ve Ahkâmın Dünyevileşmesi [Transformational Effect of Modernism: Sayyid Ahmed Khan and the 
secularization of Provisions]. Divan: Disiplinlerarası Çalı̧̧malar Dergisi, [Divan: Journal of Interdisciplinary Studies] (14), pp. 137-164.

Kavak, Ö. (2016). Fıkıh Literatüründe Cihad Hükümleri ve Modern Cihad Yorumları [Jihad Provisions in the Fiqh Literature and Modern Jihad Interpretations]. In Dağ, A. (Ed.) $\dot{I}_{c ̧}$ Tehdit ve Riskler Işı̆̆ııda İslam Dünyasının Geleceğ $i$ [The Future of the Islamic World in the Light of Internal Threats and Risks] (pp. 221-269). Istanbul, Turkey: INSAMER.

Köse, S. (2007). Cihad Şiddete Referans Olabilir Mi? [Can Jihad Be a Reference to Violence?]. İslam Hukuku Araştırmaları Dergisi. [Journal of Islamic Law Studies] (9), pp. 37-70.

Khan, M. A. (2009). Islamic Jihad: A Legacy of Forced Conversion, Imperialism, and Slavery. New York,US:iUniverse, Inc.

Kalın, I. (2016). Ben, Öteki ve Ötesi [Me, Other and Beyond]. Istanbul, Turkey: Insan Yayınları.

Ma'jam al-Lughat al-Arabiya (1994). Al-Mu'jam al-Wajiz [Concise Dictionary]. Cairo, Egypt: Wizarat at-Tarbiyya wa at-Talim.

Ma'jam al-Lughat al-Arabiya (2004). Al-Mu'jam al-Wasit. [Intermediate Dictionary]. Cairo, Egypt: Maktaba al-Shuruq al-Duwaliyya.

Muslim, B. H. (2006). Sahih Muslim. Riyadh, Saudi Arabia: Dar Tayyiba.

Omar, A. M. (2008). Mu'jam al-Lughat al-Arabiya al-Mu'asera [Contemporary Dictionary of the Language of Arabic]. Cairo, Egypt: Alim al-Kutub.

Öztürk, M. (2016). Kur'an'da Cihad. [Jihad in the Qur'an]. In Ertürk, A(Ed.). Íslam Kaynaklarında, Geleneğinde ve Günümüzde Cihad [Jihad in Islamic Sources, Tradition and Todays] (pp. 99163). Istanbul, Turkey: KURAMER.

Özel, A. (1993). Cihad. [Jihad]. Türkiye Diyanet Vakfi Islam Ansiklopedisi [Encyclopedia of Islamic Religious Foundation of Turkey] (Vol. VII, pp. 527-531). Ankara, Turkey: TDV İslam Araştırmaları Merkezi.

Pipes, D. (2002, 31 December). What is Jihad? New York Post. Retrieved from http://www. danielpipes.org/990/what-is-jihad (20.07.2019).

Party for Freedom [PVVpers] (2018, 15 March).New Video PVV on Dutch TV. Retrieved from https://www.youtube.com/watch?v=BPCwOEDkbwg (20.07.2019).

Qaradawi, Y. (2009). Fiqh al-Jihad [Jurisprudence of Jihad]. Cairo, Egypt: Maktabah Wahba.

RNS (2013). RNS-JIHAD-ADS. Religion News Service. Retrieved from

https://religionnews.com/2013/01/08/bus-ads-aim-to-reclaim-the-meaning-of-jihad/rns-jihad-ads/ (14.07.2019).

Sardar, Z. (2016). Günümüz Cihad Algısı. [Today's Perception of Jihad]. In Ertürk, A (Ed.). İslam Kaynaklarında, Geleneğinde ve Günümüzde Cihad [Jihad in Islamic Sources, Tradition and Todays] (pp. 29-34). Istanbul, Turkey: KURAMER.

Spencer, R. (2018). The History of Jihad: From Muhammad to ISIS. New York, US: Bombardier Books.

Springer, D. R., et al (2008). Islamic Radicalism and Global Jihad. Washington, D.C., US: George Town University Press. 
Tirmidhi, A. I. (1996). Sunan al-Tirmidhi. Beirut, Lebanon: Dar al-Gharb al-Islami.

Türcan, T. (2016). Fikıhta Cihad. [Jihad in Fiqh]. In Ertürk, A (Ed.). Íslam Kaynaklarında, Geleneğinde ve Günümüzde Cihad [Jihad in Islamic Sources, Tradition and Todays] (pp. 281308). Istanbul, Turkey: KURAMER.

Wilders, G. [PM Dawn] (2013, 30 March). Fitna - Geert Wilders [Full movie with English subtitles]. Retrieved from https://www.youtube.com/watch?v=2HlptyGvlIY\&has verified $=1 \& b p c t r=1544727410$ (20.07.2019).

Wood, D. [Acts17Apologetics] (2017, 28 March). Understanding Vehicular Jihad (David Wood). Retrieved from https://www.youtube.com/watch?v= oFzQSMSVgI (21.07.2019).

World Islamic Front Declaration (1998, 23 February). Federation of American Scientists. Retrieved from https://fas.org/irp/world/para/docs/980223-fatwa.htm (15.07.2019).

Yaran, C. S. (2016). Dinler ve Cihad [Religions and Jihad]. In Ertürk, A(Ed.). İslam Kaynaklarında, Geleneğinde ve Günümüzde Cihad [Jihad in Islamic Sources, Tradition and Todays] (pp. 49-77). Istanbul, Turkey: KURAMER. 